\title{
Improve Effluent Water Quality at Abu-Rawash WWTP Using Aluminum Chloride and Carbon Dioxide
}

\author{
Mohamed K. Mostafa \\ Department of Civil, Construction, and Environmental Engineering, University of Alabama at Birmingham, \\ Birmingham, AL, USA \\ Email: $\underline{\text { mkhaled@uab.edu }}$
}

Received 11 August 2015; accepted 10 September 2015; published 14 September 2015

Copyright (C) 2015 by author and Scientific Research Publishing Inc.

This work is licensed under the Creative Commons Attribution International License (CC BY). http://creativecommons.org/licenses/by/4.0/

c) (i) Open Access

\section{Abstract}

This research involved attempting to improve water quality at the Abu-Rawash WWTP by using aluminum chloride $\left(\mathrm{AlCl}_{3}\right)$ as a coagulant combined with injection of carbon dioxide $\left(\mathrm{CO}_{2}\right)$. The Abu-Rawash WWTP is the main source of water quality degradation at the Rosetta branch, Egypt. Sewage samples were collected from the effluent of the grit removal chamber. Jar tests were performed to estimate the optimum pH value and the coagulant dosage required to obtain acceptable treatment. Eleven samples were prepared with equal dosages of aluminum chloride (10.0 mg/L) and different pH values. The optimal pH values for the elimination of the biological oxygen demand (BOD), chemical oxygen demand (COD), total suspended solids (TSS), and turbidity ranged from 6.10 to 6.20 for the aluminum chloride. Results indicated that the appropriate $\mathrm{AlCl}_{3} \mathrm{dosage}$ was $2.0 \mathrm{mg} / \mathrm{L}$, especially at $\mathrm{pH}$ between 6.1 and 6.2. The results also showed that the $\mathrm{AlCl}_{3} \mathrm{was}_{\mathrm{cost}}$ effective, especially after reducing $\mathrm{pH}$ value. It is also more cost effective than the other proposed solutions such as changing the effluent path of the Abu-Rawash WWTP to the desert.

\section{Keywords}

Aluminum Chloride, Carbon Dioxide, Jar Test, Abu-Rawash WWTP, El-Rahawy Drain, Egypt

\section{Introduction}

The Abu-Rawash WWTP is the main source of pollution water quality degradation at the Rosetta branch, where it provides only a primary treatment [1]. The effluent from the plant moves along the drains until reaching the Rosetta branch in the following sequence: the Barakat drain, the Al-Ramal drain, the Al-Labene drain, the 
Al-Mariotya drain, and the El-Rahawy drain. The El-Rahawy drain is the major source of pollution along the Rosetta branch [2]. Located at El-Kanater El-Kahria area, north of Cairo, it receives water from agricultural drainage, and from Abu-Rawash and Zenen wastewater treatment plants (WWTPs) [2] [3]. Approximately 1.90 million $\mathrm{m}^{3}$ of drainage water is discharged daily from the El-Rahawy drain to the Rosetta branch, which represents about $8.80 \%$ of its maximum discharge. The drain receives about $450,000 \mathrm{~m}^{3} /$ day $(118,877,400$ gal/day) of secondary treated wastewater from the Zenen WWTP and about 1,450,000 $\mathrm{m}^{3} /$ day $(383,049,500$ gal/day) of primary treated wastewater from the Abu-Rawash WWTP [4]. The last extension allows the plant to handle an average flow of $800,000 \mathrm{~m}^{3} /$ day $\left(211,337,600\right.$ gal/day), and can handle about 1,200,000 $\mathrm{m}^{3} /$ day (437,006,400 gal/day) of peak flow [5]. The Abu-Rawash WWTP daily receives more than $1,450,000 \mathrm{~m}^{3}$ of raw wastewater, which clearly exceeds the design capacity [6]. Therefore, excess sewage is discharged directly to the El-Rahawy drain without primary treatment, which leads to increased water pollution in the El-Rahawy drain and the Rosetta branch [7]. The effluent from the plant moves along the drains until reaching the Rosetta branch in the following sequence: the Barakat drain, the Al-Ramal drain, the Al-Labene drain, the Al-Mariotya drain, and the El-Rahawy drain, as shown in Figure 1. The average concentrations of chemical oxygen demand (COD), biological oxygen demand (BOD), total suspended solids (TSS), total dissolved solids (TDS), total organic carbon (TOC), and dissolved oxygen (DO) in the El-Rahawy drain were 270, 146.7, 159.25, 720, 9.2, and $1.45 \mathrm{mg} / \mathrm{L}$, respectively [4]. Because the Abu-Rawash WWTP provides only primary treatment, the effluent water quality does not meet the legal requirements specified in Egyptian law 48/1982 (see Table 1). An area of 2500 acres northwest of Cairo is irrigated with the Abu-Rawash WWTP effluent, and discharging primary treated wastewater from the Abu-Rawash WWTP may affect not only the quality of water but also the quality of the agricultural crops [4].

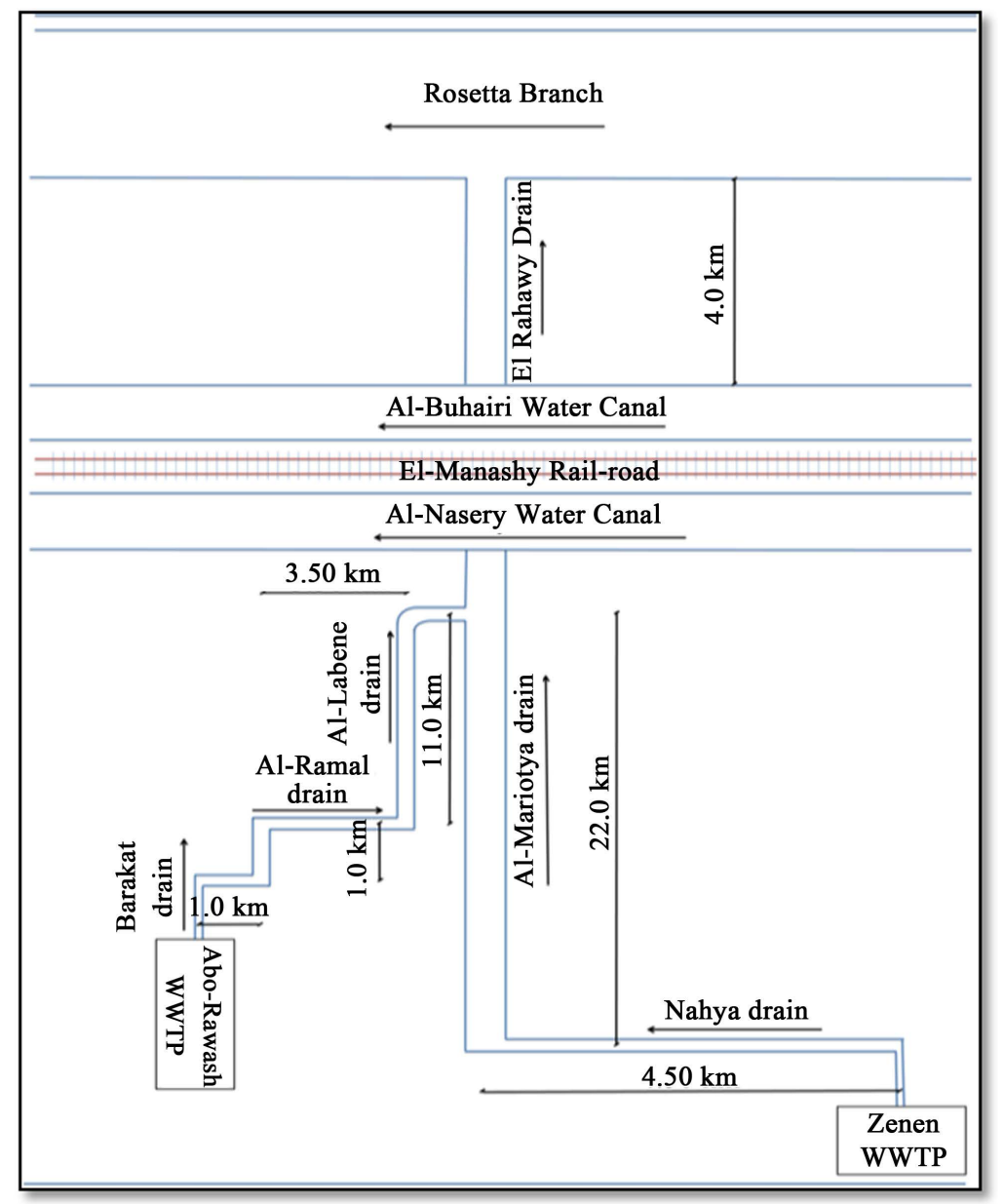

Figure 1. Discharging the Abu-Rawash effluent to the Rosetta branch [4]. 
Table 1. Analysis of raw and treated wastewater from the Abu-Rawash WWTP [4].

\begin{tabular}{cccccccc}
\hline \multirow{2}{*}{ Parameter } & \multicolumn{3}{c}{ Raw sewage } & \multicolumn{3}{c}{ Treated wastewater } & \multicolumn{2}{c}{ Egyptian law } \\
\cline { 2 - 7 } & Minimum & Average & Maximum & Minimum & Average & Maximum & $48 / 1982$ \\
\hline COD, mg/L & 290.0 & 332.50 & 375.0 & 179.0 & 209.50 & 240.0 & $<30.0$ \\
BOD, mg/L & 140.0 & 165.0 & 190.0 & 84.0 & 99.0 & 114.0 & $<20.0$ \\
TSS, mg/L & 164.0 & 210.0 & 256.0 & 70.80 & 92.40 & 114.0 & $<20.0$ \\
Turbidity, NTU & 31.0 & 38.0 & 45.0 & 14.0 & 19.0 & 24.0 & $<50.0$ \\
pH & 7.10 & 7.20 & 7.30 & 7.40 & 7.45 & 7.50 & $06-09$ \\
DO, mg/L & 0.16 & 0.355 & 0.55 & 0.50 & 0.955 & 1.41 & $>5.0$ \\
TOC, mg/L & 13.15 & 15.20 & 17.25 & 8.40 & 9.70 & 11.0 & $<3.0$ \\
TDS, mg/L & 874.0 & 946.0 & 1018.0 & 865.0 & 937.0 & 1007.0 & $<500.0$ \\
\hline
\end{tabular}

COD: Chemical Oxygen Demand; BOD: Biological Oxygen Demand; TSS: Total Suspended Solids; DO: Dissolved Oxygen; TOC: Total Organic Carbon; TDS: Total Dissolved Solids.

Several studies have been conducted to address water quality degradation at the El-Rahawy drain due to receiving discharge from Abu-Rawash WWTP. Abdel-Satar and Elewa (2001) observed high levels of physicochemical parameters at the discharge point of the El-Rahawy drain [8]. Abdo (2002) concluded that the El-Rahawy drain comprised the major source of pollutants along the Rosetta branch [9]. Elewa et al. (2009) and Badr et al. (2006) concluded that the El-Rahawy drain was the major source of pollution along the Rosetta branch because the drain discharged large amounts of agricultural and domestic wastewaters [2] [10]. Other studies of water quality at the Rosetta branch included that of were conducted by Moustafa et al. (2010), who conducted a study to assess the water quality of the Rosetta branch [11]. They collected water samples from different points along the branch for analysis; results of the analyses revealed low levels of DO, as well as high concentrations of BOD, COD, total dissolved solids (TDS), and bicarbonate $\left(\mathrm{HCO}_{3}\right)$, at the discharge point of El-Rahawy drain. Ezzat et al. (2012) assessed the water quality of the Rosetta branch and the main drains located along its path [12]. Analysis of water samples collected from the Rosetta branch and from drains discharging into the Rosetta branch, yielded results revealing that the water quality along the studied area was affected by the discharge of the drains, especially the El-Rahawy drain. Elevated concentrations of ammonia $\left(\mathrm{NH}_{3}\right)$, electrical conductivity (EC), TDS, BOD, DO, turbidity, and total alkalinity were recorded [12].

Several studies were conducted to improve effluent quality from WWTPs. A case study was conducted to evaluate the effectiveness of ferric chloride and alum in wastewater treatment [13]. Ferric chloride and alum were evaluated by using a series of jar tests, and findings indicated optimum alum and ferric chloride doses of 80 and $40 \mathrm{mg} / \mathrm{L}$, respectively. Because ferric chloride showed the highest removal efficiency, with the application of $40 \mathrm{mg} / \mathrm{L}$ of ferric chloride causing reductions in COD, TSS, and turbidity up to 74\%, $91 \%$, and $79 \%$, respectively, using this substance has proven more cost effective than using alum [13]. In that same study, the authors investigated the effectiveness of quicklime and Moringa seeds in wastewater treatment [13]. Jar tests were also used to evaluate the effectiveness of quicklime and Moringa seed dosages. In the study, the application of $500 \mathrm{mg} / \mathrm{L}$ of quicklime caused reductions in COD, BOD, VSS, TSS, fecal coliforms, total coliforms, and turbidity up to $78.2 \%, 78.9 \%, 98.6 \%, 97.8 \%, 99.99 \%, 99.99 \%$, and $95.5 \%$, respectively. Application of $10 \mathrm{ml} / \mathrm{L}$ of water extract from dry Moringa seeds caused reductions in BOD, COD, TSS, VSS, turbidity, fecal coliforms, and total coliforms up to 32\%, 48\%, 92\%, 94\%, 85\%, 89.6\%, and 89.1\%, respectively. Quicklime increases $\mathrm{pH}$ value and produces large amounts of sludge, whereas the Moringa seeds have a minor effect on $\mathrm{pH}$ value; therefore, the authors recommended using Moringa seeds instead of quicklime in wastewater treatment [13].

\section{Materials and Methods}

This research involved attempting to improve water quality at the Abu-Rawash WWTP by using aluminum chloride $\left(\mathrm{AlCl}_{3}\right)$ as a coagulant, with injections of carbon dioxide $\left(\mathrm{CO}_{2}\right) \cdot \mathrm{CO}_{2}$ was injected into the wastewater in order to reduce the $\mathrm{pH}$ value. Jar tests were performed to estimate the optimum $\mathrm{pH}$ value and the coagulant 
dosage required to produce an acceptable treatment. A comparison was also conducted between using aluminum chloride alone and using aluminum chloride with injections of $\mathrm{CO}_{2}$ in wastewater treatment.

Sewage samples were collected in 10.0 liter plastic containers from the effluent of the grit removal unit. The average sludge volume index (SVI) was recorded for Abu-Rawash WWTP as $126 \mathrm{~mL} / \mathrm{g}$ [14]. Wastewater samples were placed in an ice box for transfer to the laboratory. Six jars were filled to the 1.0 liter mark with the wastewater. Coagulant doses were added into jars in different proportions and then jars were placed in a stirrer with paddles. Standard mixing and flocculation durations and speeds were employed. The paddles were operated at high speed of $150 \mathrm{rpm}$ for one minute. Then, the mixing speed reduced to $30 \mathrm{rpm}$ for 10 minutes. Last, a quiescent settling was allowed for 45 minutes [4]. The resulting liquid samples were then analyzed for TDS, TSS, COD, BOD, TOC, $\mathrm{pH}$, and turbidity. The HM digital TDS meter was used to measure the TDS concentration in the field. For quality control purposes, a solution with known concentration allowed assessment of the accuracy of measurements. The WTW multi 340i meter enabled measurement of DO and pH values in the field. The meter automatically adjusts DO. Three buffer solutions with $\mathrm{pH}$ values of 4.0, 7.0, and 10.0 were used for the multi meter calibration. Analysis of the other parameters took place in Egyptian Housing Building Research Center (HBRC) laboratory, located in Cairo city. This laboratory received an ISO 9000 award for quality assurance. The samples were analyzed for different parameters according to the standard methods for wastewater analysis [15]. The TOC concentration was measured in the laboratory by using a Shimadzu TOC-4200 analyzer; an automatic calibration conducted by using dilution water as a standard solution ascertained the accuracy of the data. Turbidity was measured by using the turbidity meter. Test method 2540D was used for the determination of TSS. For quality control purposes, analysis of $20 \%$ of the total number of sample took place. Use of the closed reflux, titrimetric method 5220C enabled determination of the COD concentration in the samples. For quality control purposes, testing of a solution with known concentration ensured accuracy of the measurements. The 5-day BOD Test 5210Bwas used in the determination of the BOD concentration in wastewater samples. For quality control purposes, the research protocol included the following procedures: (1) In seed control samples tested after 5 days of incubation, a minimum residual DO of $1.0 \mathrm{mg} / \mathrm{L}$ and a minimum DO depletion of $2.0 \mathrm{mg} / \mathrm{L}$ were required; (2) the glucose-glutamic acid solution and the dilution water were tested and compared with the acceptable limits.

Then, the removal efficiency was calculated by using the following formula:

$$
\% \text { Removal }=100\left[\left(C_{0}-C\right) / C_{0}\right]
$$

where $C_{0}=$ parameter concentration before coagulation treatment; $C=$ parameter concentration after coagulation treatment.

As shown in Figure 1, the effluents from Abu-Rawash and Zenen WWTPs move along the drains until reaching the El-Rahawy drain. So, the exponential equation was used to calculate the concentration of different parameters directly before pouring to the El-Rahawy drain.

$$
C=C_{o} \times \mathrm{e}^{(-k x / v)}
$$

where: $C=$ pollutant concentration at any point located after the point source, $\mathrm{mg} / \mathrm{L}$

$C_{0}=$ pollutant concentration immediately downstream of the injection point, $\mathrm{mg} / \mathrm{L}$

$x=$ distance downstream of the injection point, $\mathrm{m}$

$v=$ velocity in the river, $\mathrm{m} /$ day

A first-order decay of organic pollutants was assumed. The first-order decay was assumed to be equal to 0.1 day $^{-1}$ at $20^{\circ} \mathrm{C}$ [16]. Equation (2) was used to estimate the decay rate at any water temperature; this decay rate depends mainly on the water temperature [16].

$$
K_{T}=K_{20{ }^{\circ} \mathrm{C}} \times 1.047^{(T-20)}
$$

\section{Results and Discussion}

A series of jar tests were used to evaluate the effectiveness of $\mathrm{AlCl}_{3}$ at normal $\mathrm{pH}$ value and $\mathrm{AlCl}_{3}$ at lower $\mathrm{pH}$ value in wastewater treatment. At the normal $\mathrm{pH}$ value 7.20, aluminum chloride was added into jars in 6 different doses. The minimum $\mathrm{pH}$ value recommended for $\mathrm{AlCl}_{3}$ is 5 [17]. The dosages selected were $5,8,10,15,20$, and $25 \mathrm{mg} / \mathrm{L}$. A blank jar with no coagulant was also prepared. The jar tests were performed as mentioned before. Samples were analyzed for BOD, COD, TSS, and turbidity, and the removal efficiencies are shown in 
Figure 2. To reach an acceptable treatment, a dose of $10.0 \mathrm{mg}$ of $\mathrm{AlCl}_{3}$ for each liter of wastewater was selected.

The initial BOD concentration was recorded to be $169 \mathrm{mg} / \mathrm{L}$. Application of $10.0 \mathrm{mg} / \mathrm{L}$ of aluminum chloride at $\mathrm{pH} 7.20$ reduced the BOD concentration at the effluent from $169.0 \mathrm{mg} / \mathrm{L}$ to $60.0 \mathrm{mg} / \mathrm{L}$. The maximum removal efficiency of BOD was $64.30 \%$, whereas it was limited to $40.0 \%$ for the blank sample. For the same dose, the TSS, COD, turbidity, TDS, and TOC reached maximum removal efficiencies of $78.50 \%, 65.80 \%, 77.40 \%$, $62.47 \%$, and $63.15 \%$, respectively.

$\mathrm{pH}$, is an important factor for proper coagulation performance, it can affect the coagulant solubility and the surface charge of floc particles. Eleven samples were prepared with equal dosages of aluminum chloride (10.0 $\mathrm{mg} / \mathrm{L}$ ) and different $\mathrm{pH}$ values. The $\mathrm{pH}$ value was adjusted using the WTW multi 340i meter. The optimal $\mathrm{pH}$ values for the elimination of the BOD, COD, TSS, and turbidity ranged from 6.10 to 6.20 for the aluminum chloride (see Figure 3). For high alkalinity wastewater, excessive amounts of coagulant are required to lower the $\mathrm{pH}$ to the optimal $\mathrm{pH}$ range. In these cases, it may be beneficial to add carbon dioxide in addition to the aluminum chloride to reduce the amount of aluminum chloride needed and thus reduce the chemical costs.

After the above results were found, carbon dioxide was injected into the sewage sample in order to reduce $\mathrm{pH}$ to values between 6.10 and 6.20. When the $\mathrm{pH}$ level was reduced, six different doses of aluminum chloride were applied into the beakers, each containing $1.0 \mathrm{~L}$ of sewage. Very low doses of aluminum chloride were selected in order to reach an acceptable treatment with the least possible cost. The doses were $0.40,2.0,3.50,6.50,8.0$, and 10.0 $\mathrm{mg} / \mathrm{L}$. A blank jar with no coagulant was also prepared. The jar tests were performed as mentioned before. Samples

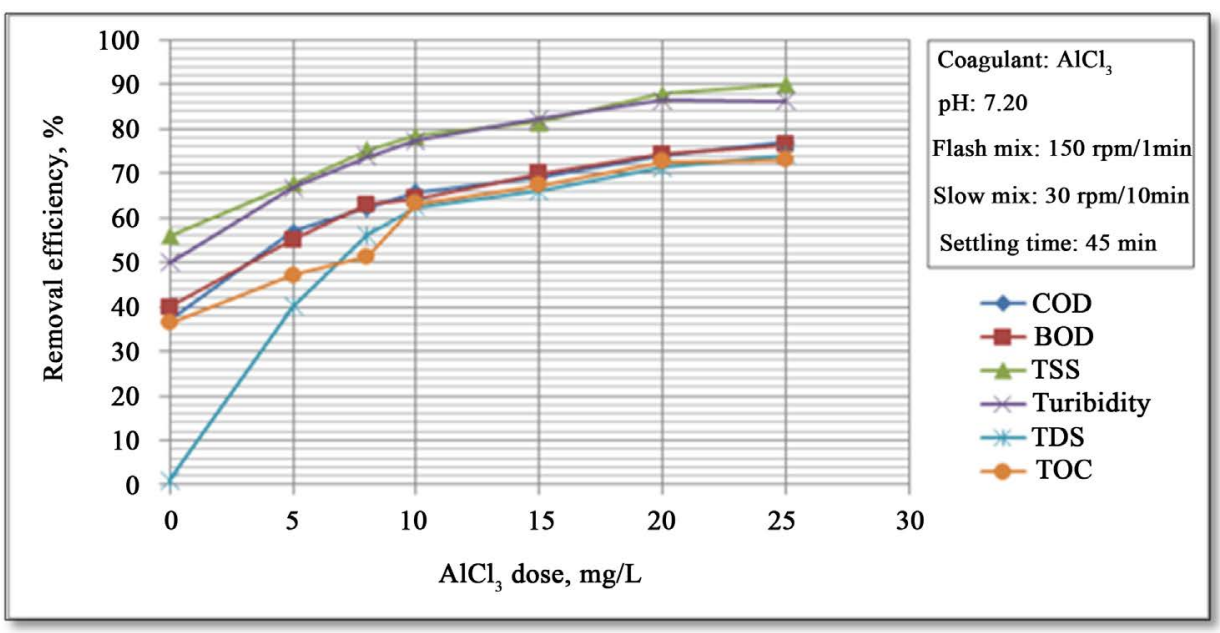

Figure 2. Effect of aluminum chloride doses on BOD, COD, TSS, and turbidity removal efficiencies.

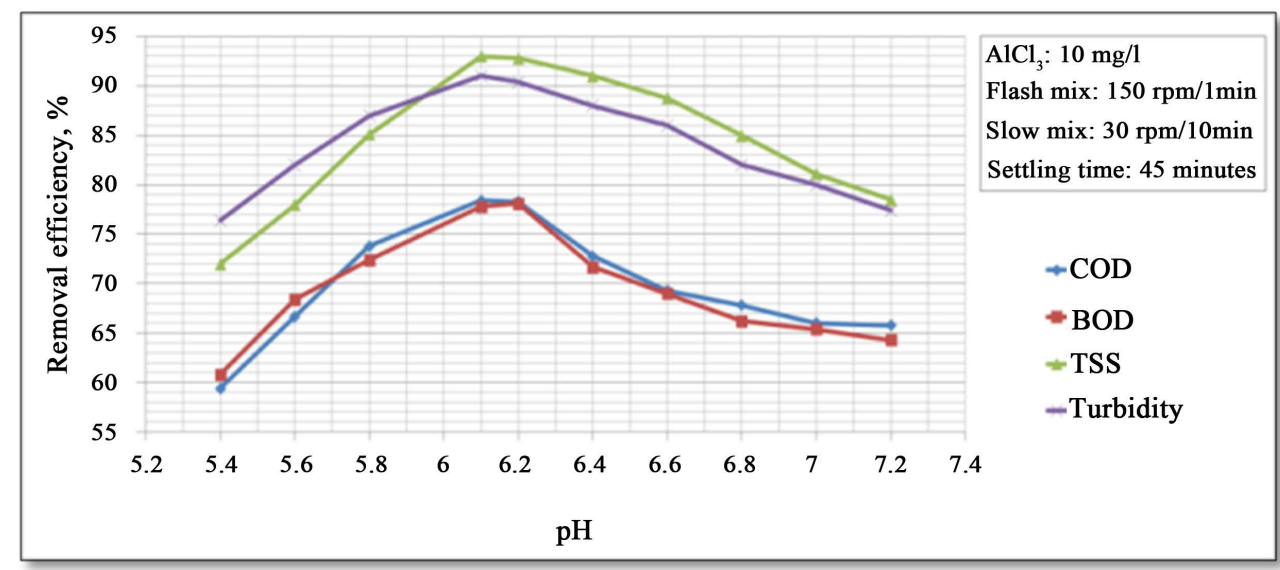

Figure 3. Removal efficiency of COD, BOD, TSS, and turbidity by aluminum chloride at different $\mathrm{pH}$ values. 
were analyzed for different parameters, and the removal efficiencies are shown in Figure 4. To reach an acceptable treatment with the least possible cost, a dose of $2.0 \mathrm{mg}$ of $\mathrm{AlCl}_{3}$ for each liter of wastewater was selected.

The initial BOD concentration was $169 \mathrm{mg} / \mathrm{L}$. Application of $2.0 \mathrm{mg} / \mathrm{L}$ of aluminum chloride at $\mathrm{pH} 6.14$ reduced the BOD concentration at the effluent from $169.0 \mathrm{mg} / \mathrm{L}$ to $57.60 \mathrm{mg} / \mathrm{L}$. The maximum removal efficiency of BOD was $66.0 \%$, whereas it was limited to $40.0 \%$ for the blank sample. For the same dose, the COD, TSS, turbidity, TDS, and TOC reached maximum removal efficiencies of $67.60 \%, 82.20 \%, 80.10 \%, 64.60 \%$, and $61.80 \%$, respectively.

Comparison between the two tests was conducted and the results showed that adding $2.0 \mathrm{mg} / \mathrm{L}$ of aluminum chloride at pH 6.14 results in a removal efficiency nearly equal to that of $10.0 \mathrm{mg} / \mathrm{L}$ of aluminum chloride at $\mathrm{pH}$ 7.20, as shown in Figure 5. Consequently, reducing the $\mathrm{pH}$ level from 7.20 to 6.14 has significantly improved the removal efficiency of contaminants. Since, most of the aquatic life can survive at $\mathrm{pH}$ value range from 6 to 9 [4], reducing $\mathrm{pH}$ value to 6.14 will not adversely affect flora and fauna.

The average concentrations of BOD, COD, TSS, TDS, TOC, and DO at the effluent of Abu-Rawash WWTP after applying $2.0 \mathrm{mg} / \mathrm{L}$ of $\mathrm{AlCl}_{3}$ at $\mathrm{pH} 6.14$ were recorded to be 57.60, 106, 41.50, 355, 5.60, and $0.92 \mathrm{mg} / \mathrm{L}$, respectively. Twenty samples were collected from the effluent of the Zenen WWTP and the average COD, BOD, TSS, TDS, TOC, and DO concentrations were recorded to be 70.0, 34.50, 30.0, 412.0, 1.50, and $4.50 \mathrm{mg} / \mathrm{L}$, respectively. Since the effluents from Zenen and Abu-Rawash plants move along the drains until reaching the El-Rahawy drain. So, the exponential equation was used to calculate the concentration of different parameters directly before pouring to the El-Rahawy drain. The decay rate was found to be equal to 0.108 day $^{-1}$ at $21.7^{\circ} \mathrm{C}$ (average water temperature at the drains). For Zenen WWTP, the estimated concentrations of COD, BOD, TSS, TDS, TOC, and DO directly before pouring to the El-Rahawy drain were 66.0, 32.50, 28.25, 388.0, 1.41, and

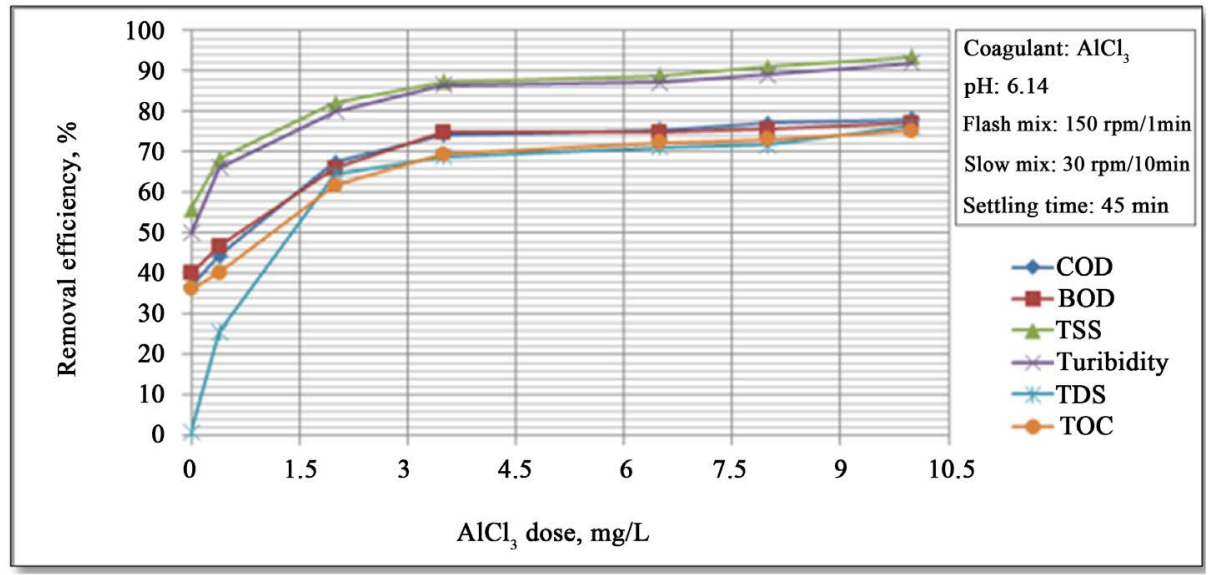

Figure 4. Effect of carbon dioxide and aluminum chloride doses on BOD, COD, TSS, and turbidity removal efficiencies.

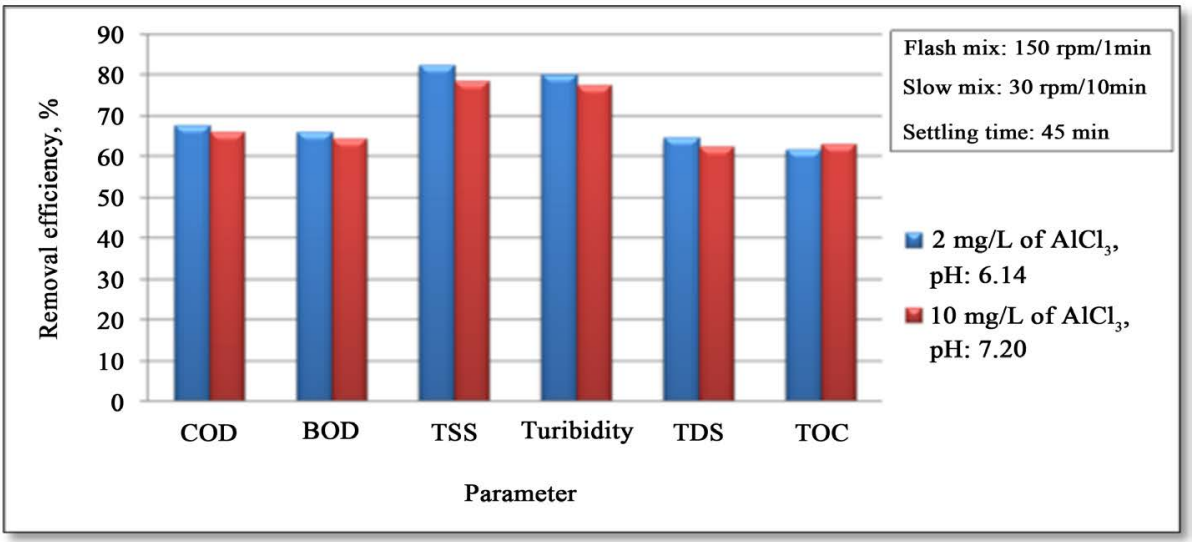

Figure 5. Removal efficiencies when applying aluminum chloride at different $\mathrm{pH}$ values. 
$4.24 \mathrm{mg} / \mathrm{L}$, respectively. The average value for $\mathrm{pH}$ in Zenen WWTP effluent was recorded to be 7.4. For Abu-Rawash WWTP, the estimated concentrations of COD, BOD, TSS, TDS, TOC, and DO directly before pouring to the El-Rahawy drain were $102.10,55.50,40.0,342.0,5.40$, and $0.89 \mathrm{mg} / \mathrm{L}$, respectively.

Mass balances were involved to estimate the concentrations of different parameters at the El-Rahawy drain after effluent water quality was improved at the Abu-Rawash WWTP, as shown in the equations below. Reaching an acceptable treatment was accomplished by selecting a dose of $2.0 \mathrm{mg}$ of aluminum chloride for each liter of wastewater. The carbon dioxide was used to reduce the $\mathrm{pH}$ to the values between 6.10 and 6.20. Improving effluent water quality at the Abu-Rawash WWTP reduced the COD concentration at the El-Rahawy drain from $270.0 \mathrm{mg} / \mathrm{L}$ to $94.0 \mathrm{mg} / \mathrm{L}$. Applying this approach will increase the DO concentration at the El-Rahawy drain by about $17.20 \%$, and reduce the levels of TSS, BOD, TOC, and, turbidity by $76.60 \%, 66.0 \%, 51.50 \%$,and $79.10 \%$, respectively.

$$
\left(Q_{\text {Abu-Rawash WWTP }} \times C_{\text {Abu-Rawash WWTP }}\right)+\left(Q_{\text {Zenen WwTP }} \times C_{\text {Zenen WWTP }}\right)=Q_{\text {El-Rahawy drain }} \times C_{\text {El-Rahawy drain }}
$$

For BOD:

$$
\begin{gathered}
\left(1.45 \times 10^{6} \mathrm{~m}^{3} \times 55.50 \mathrm{mg} / \mathrm{L}\right)+\left(4.50 \times 10^{5} \mathrm{~m}^{3} \times 32.50 \mathrm{mg} / \mathrm{L}\right)=1.90 \times 10^{6} \mathrm{~m}^{3} \times C_{\text {El-Rahawy drain }} \\
\therefore C_{\text {El-Rahawy drain }}=50.0 \mathrm{mg} / \mathrm{L}
\end{gathered}
$$

For TSS:

$$
\begin{gathered}
\left(1.45 \times 10^{6} \mathrm{~m}^{3} \times 40.0 \mathrm{mg} / \mathrm{L}\right)+\left(4.50 \times 10^{5} \mathrm{~m}^{3} \times 28.25 \mathrm{mg} / \mathrm{L}\right)=1.90 \times 10^{6} \mathrm{~m}^{3} \times C_{\text {El-Rahawy drain }} \\
\therefore C_{\text {El-Rahawy drain }}=37.22 \mathrm{mg} / \mathrm{L}
\end{gathered}
$$

For COD:

$$
\begin{gathered}
\left(1.45 \times 10^{6} \mathrm{~m}^{3} \times 102.10 \mathrm{mg} / \mathrm{L}\right)+\left(4.50 \times 10^{5} \mathrm{~m}^{3} \times 66.0 \mathrm{mg} / \mathrm{L}\right)=1.90 \times 10^{6} \mathrm{~m}^{3} \times C_{\text {El-Rahawy drain }} \\
\therefore C_{\text {El-Rahawy drain }}=94.0 \mathrm{mg} / \mathrm{L}
\end{gathered}
$$

For TDS:

$$
\begin{gathered}
\left(1.45 \times 10^{6} \mathrm{~m}^{3} \times 342.0 \mathrm{mg} / \mathrm{L}\right)+\left(4.50 \times 10^{5} \mathrm{~m}^{3} \times 388.0 \mathrm{mg} / \mathrm{L}\right)=1.90 \times 10^{6} \mathrm{~m}^{3} \times C_{\text {El-Rahawy drain }} \\
\therefore C_{\text {El-Rahawy drain }}=353.0 \mathrm{mg} / \mathrm{L}
\end{gathered}
$$

For DO:

$$
\begin{gathered}
\left(1.45 \times 10^{6} \mathrm{~m}^{3} \times 0.89 \mathrm{mg} / \mathrm{L}\right)+\left(4.50 \times 10^{5} \mathrm{~m}^{3} \times 4.24 \mathrm{mg} / \mathrm{L}\right)=1.90 \times 10^{6} \mathrm{~m}^{3} \times C_{\text {El-Rahawy drain }} \\
\therefore C_{\text {El-Rahawy drain }}=1.70 \mathrm{mg} / \mathrm{L}
\end{gathered}
$$

For TOC:

$$
\begin{gathered}
\left(1.45 \times 10^{6} \mathrm{~m}^{3} \times 5.40 \mathrm{mg} / \mathrm{L}\right)+\left(4.50 \times 10^{5} \mathrm{~m}^{3} \times 1.41 \mathrm{mg} / \mathrm{L}\right)=1.90 \times 10^{6} \mathrm{~m}^{3} \times C_{\text {El-Rahawy drain }} \\
\therefore C_{\text {El-Rahawy drain }}=4.46 \mathrm{mg} / \mathrm{L}
\end{gathered}
$$

For $\mathrm{pH}$ :

$$
\begin{gathered}
Q_{\text {Abu-Rawash WWTP }} \times\left(10^{\left.-\mathrm{pH}_{\text {Abu-Rawash WWTP }}\right)+} Q_{\text {Zenen WWTP }} \times\left(10^{-\mathrm{pH}_{\text {Zenen }} \text { WTP }}\right)=Q_{\text {El-Rahawy drain }} \times\left(10^{- \text {pHEl-Rahawy drain }}\right)\right. \\
=1.45 \times 10^{6} \mathrm{~m}^{3} \times\left(10^{-6.14}\right)+4.50 \times 10^{5} \mathrm{~m}^{3} \times\left(10^{-7.40}\right)=1.90 \times 10^{6} \mathrm{~m}^{3} \times\left(10^{-\mathrm{pH}_{\text {El-Rhawy drain }}}\right) \\
\therefore \mathrm{pH}_{\text {El-Rahawy drain }}=6.25
\end{gathered}
$$

\section{Economical Study}

Cost is one of the most important parameter in wastewater treatment. Assume that the effective doses of aluminum chloride at pH equal 7.2 and 6.14 are 10 and $2 \mathrm{mg} / \mathrm{L}$, respectively. The cost estimation for each case is presented in Table 2. The cost of aluminum chloride to treat one cubic meter of wastewater at pH equal 7.2 and 6.14 
Table 2. Treatment cost estimation at different $\mathrm{pH}$ values.

\begin{tabular}{ccc}
\hline Term & $\mathrm{pH}: 6.14$ & $\mathrm{pH}: 7.20$ \\
\hline $\mathrm{AlCl}_{3}$ dose, $\mathrm{mg} / \mathrm{L}$ & 2.0 & 10.0 \\
$\mathrm{AlCl}_{3}$ dose, ton $/ \mathrm{m}^{3}$ & 0.000002 & 0.00001 \\
$\mathrm{AlCl}_{3}$ cost, EGP/ton & 1300 & 1300 \\
$\mathrm{AlCl}_{3}$ cost, EGP $/ \mathrm{m}^{3}$ & 0.0026 & 0.013 \\
Carbon dioxide cost, EGP $/ \mathrm{m}^{3}$ & 0.0008 & $\mathrm{~N} / \mathrm{A}$ \\
Total cost, EGP $/ \mathrm{m}^{3}$ & 0.0034 & 0.013 \\
Total cost, dollar $/ \mathrm{m}^{3}$ & 0.000485 & 0.00185 \\
\hline
\end{tabular}

$\mathrm{AlCl}_{3}$ : Aluminum Chloride; EGP: Egyptian Pound.

is 0.013 and 0.0034 Egyptian Pounds (EGP), respectively. Ashmawy et al. (2012) investigated the effectiveness of different coagulants in wastewater treatment. The cost of quicklime, ferric chloride, and alum to treat one cubic meter of wastewater and reach similar acceptable treatment was found to be $0.075,0.04$, and $0.1 \mathrm{EGP}$, respectively [13]. According to these results, aluminum chloride was found to be cost effective, especially after reducing $\mathrm{pH}$ value. This solution is more cost effective than the other proposed solutions such as changing the effluent path of the Abu-Rawash WWTP to the desert at a cost of about 400 million EGP (\$57.14 million) for constructing a canal 32 kilometers long [4].

\section{Conclusion}

Results showed that the efficiency of aluminum chloride in treatment of wastewater increased when reducing $\mathrm{pH}$, where adding $2.0 \mathrm{mg} / \mathrm{L}$ of aluminum chloride and injecting $\mathrm{CO}_{2}$ yields a removal efficiency equal to that of adding $10.0 \mathrm{mg} / \mathrm{L}$ of aluminum chloride with no $\mathrm{CO}_{2}$ inject. Application of $2.0 \mathrm{mg} / \mathrm{L}$ of aluminum chloride and injecting $\mathrm{CO}_{2}$ caused reductions in TOC, TSS, COD, BOD, TDS, and turbidity reaching $61.80 \%, 82.20 \%$, $80.10 \%, 66.0 \%, 64.60 \%$, and $79.60 \%$, respectively. In addition, the cost of treating wastewater by using aluminum chloride was reduced by $82.50 \%$ when the $\mathrm{pH}$ value was reduced from 7.2 to 6.15 . Applying this approach will increase the DO concentration at the El-Rahawy drain by about $17.20 \%$, and will decrease the TDS, TOC, BOD, TSS, and COD concentrations by about $51.0 \%$, 51.50\%, 66\%, 76.60\%, and 65.20\%, respectively. Applying the proposed solution is currently possible, especially because of its cost-effectiveness which exceeds that of the other proposed solutions such as changing the effluent path of the Abu-Rawash WWTP to the desert.

\section{Acknowledgements}

This research was supported by the Department of Civil, Construction, and Environmental Engineering at the University of Alabama at Birmingham. The author also thanks the Egyptian Housing Building Research Center for their help in collecting samples and performing the chemical analyses.

\section{References}

[1] El-Bouraie, M.M., Eman, A.M., Gehad, G.M., Essam, H.A. and Mohamed, M.Y. (2011) Water Quality of Rosetta Branch in Nile Delta, Egypt. Suoseura, 62, 31-37.

[2] Elewa, A.A., Shehata, M.B., Mohamed, L.F., Badr, M.H. and Abdel-Aziz, G.S. (2009) Water Quality Characteristics of the River Nile at Delta Barrage with Special Reference to Rosetta Branch. Global Journal of Environment Research, 3, 1-6.

[3] Gaber, H.S., Midhat, A.E., Seham, A.I. and Mohammad, M.N.A. (2013) Effect of Water Pollution in El-Rahawy Drainage Canal on Hematology and Organs of Freshwater Fish Clarias gariepinus. World Applied Sciences Journal, 21, 329-341.

[4] Mostafa, M. (2014) Modeling of Pollutant Transport in the Nile Delta Egypt. PhD. Dissertation, Department of Civil, construction, and Environmental Engineering, University of Alabama at Birmingham, Birmingham.

[5] El-Fakharany, Z.M. (2013) Environmental Impact Assessment of Artificial Recharge of Treated Wastewater on Groundwater Aquifer System Case study Abu-Rawash, Egypt. The Journal of American Science, 9, 309-315.

[6] Ministry of Housing, Utilities and Urban Development (2010) Availability and Operation of Abu-Rawash Wastewater 
Treatment Plant: Amended Information Memorandum. http://www.investment.gov.eg/en/Documents/AbuRawashIMFINALclean.pdf

[7] Misheloff, R. (2010) Integrated Water Resource Management II: Feasibility of Wastewater Reuse, International Resources Group. Report No.14, United States Agency for International Development (USAID), Washington DC.

[8] Abdel-Satar, A.M. and Elewa, A.A. (2001) Water Quality and Environmental Assessments of the River Nile at Rosetta Branch. 2nd International Conference and Exhibition for Life and Environment, Alexandria, 3-5 April 2001, 136-164.

[9] Abdo, M.H. (2002) Environmental Studies on Rosetta Branch and Some Chemical Applications at the Area Extend from El-Kanater El-Khyria to Kafr-El-Zyat City. Ph.D Thesis, Ain Shams University, Cairo, Egypt.

[10] Badr, M.H., Abdelsamie, E., Mohammed, B.S., Laila, F.M., and Ghada, S.A. (2006) Studies on the Effect of El-Rahaway Drain on the River Nile Water Pollution by Trace Metals and Major Cations at El-Kanater-El Khyria Area Under the Effect of Seasonal Variation. The Assiut University Bulletin for Environmental Researches, 9, 205-218.

[11] Moustafa, M.M., Mohamed, H.H.A., Amal, M.A., Talat, M. and Siliem, M.M. (2010) Water Quality Assessment of Rosetta and Damietta Branches, River Nile, Egypt. African Journal of Biology, 6, 127-142.

[12] Ezzat, S.M., Hesham, M.M., Mervat, A.A., Essam, H.A. and Mostafa, A.E. (2012) Water Quality Assessment of River Nile at Rosetta Branch: Impact of Drains Discharge. Middle-East Journal of Scientific Research, 12, 413-423.

[13] Ashmawy, M.A., Moussa, M.S., Ghoneim, A.K., and Tammam, A. (2012) Enhancing the Efficiency of Primary Sedimentation in Wastewater Treatment Plants with the Application of Moringa oliefera Seeds and Quicklime. Journal of American Science, 8, 494-502.

[14] Mostafa, A.H. (2012) Effect of Cement Kiln Dust Addition on Activated Sludge Process without Primary Settling for Reuse Applications. HBRC Journal, 8, 14-25. http://dx.doi.org/10.1016/j.hbrcj.2012.08.003

[15] Andrew, D.E., Lenore S.C., Eugene W.R. and Arnold E.G. (2005) Standard Methods for the Examination of Water and Wastewater. 21st Edition, American Public Health Association, Washington DC.

[16] Jolankai, G. (1997) Basic River Water Quality Models. International Hydrological Programme, the United Nations Educational, Scientific and Cultural Organization (UNESCO), Paris.

[17] Kumar, P., Tjoon, T.T., Shri, C. and Kailas, L.W. (2011) Treatment of Paper and Pulp Mill Effluent by Coagulation. International Scholarly and Scientific Research and Innovation, 5, 967-972. 